\title{
New species and records of the genus Aegla Leach, 1820 (Crustacea, Anomura, Aeglidae) from the West-Central region of Rio Grande do Sul, Brazil
}

Sandro Santos, Carlos G. Jara, Marlise Ladvocat Bartholomei-Santos, Marcos Pérez-Losada and Keith A. Crandall

(SS, MLB-S) Departamento de Biologia, Universidade Federal de Santa Maria, 97105-900, Santa Maria, RS, Brasil. E-mail: ssantos@smail.ufsm.br.

(CGJ) Instituto de Zoología, Universidad Austral de Chile, Campus Isla Teja, Casilla 567, Valdivia, Chile.

(MP-L) CIBIO, Centro de Investigação em Biodiversidade e Recursos Genéticos, Universidade do Porto, Campus Agrário de Vairão, 4485-661, Vairão, Portugal.

(KAC, SS, MLB-S) Computational Biology Institute, George Washington University, Ashburn, VA, 20147, U.S.A.

(KAC) Department of Invertebrate Zoology, National Museum of Natural History, Smithsonian Institution, Washington DC, 20013, U.S.A.

\begin{abstract}
Aeglidae are anomuran freshwater "crabs" found only in southern South America. In Brazil, the greatest species diversity occurs in hydrographic basins of the state of Rio Grande do Sul. Two new species, Aegla georginae and Aegla ludwigi, are described from the Ibicuí and Ijuí Rivers, respectively (Uruguay River Basin). The new taxa can be distinguished from other Aegla species based on both morphological and molecular characters. The two new species have a very restricted distribution and are categorized as endangered (A. georginae) and critically endangered (A. ludwigi) using IUCN Red List criteria. We also summarize and present new records of the Aegla species occurring in the Uruguay River Basin.
\end{abstract}

Key words: Aeglidae, Aegla, Brazil, freshwater biodiversity, molecular systematics, taxonomy

\section{INTRODUCTION}

Members of the family Aeglidae are unique among the infraorder Anomura because the whole group is entirely restricted to freshwater environments and to the Neotropical region of South America (Bond-Buckup and Buckup, 1994). The uniqueness of some of its morphological characters and its distinctive phylogenetic position (Pérez-Losada et al., 2002) led to the reclassification of Aeglidae in a separate super-family, Aegloidea (McLaughlin et al., 2007).

The family Aeglidae comprises only one extant genus, Aegla Leach, 1820, with a surprising diversity, compared to crayfishes of the family Parastacidae (Crandall et al., 2000) and brachyuran crabs of the genus Trichodactylus (Yeo et al., 2006), also inhabiting southern South America waters. The first aeglid species was described in 1818 by Latreille, followed by three Aegla species described by the end of the $19^{\text {th }}$ century (Bond-Buckup and Buckup, 1994). No new aeglids were described until the 1940 's, when 15 species were described by Schmitt and two by Ringuelet (Bond-Buckup and Buckup, 1994). After a second period of 
stagnation, from 1972 onward the number of known Aegla species increased significantly, mainly due the contributions of C. Jara (Chile) and L. Buckup and G. Bond-Buckup (Brazil). Currently, a total of 72 species have been described (McLaughlin et al., 2010; Santos et al., 2012). Of these, at least 25 Aegla species are under threat, according to the IUCN (2001) criteria (Bond-Buckup et al., 2008), including some species recently described such as the vulnerable $A$. manuinflata Bond-Buckup and Santos, 2009, A. leachi Bond-Buckup and Buckup, 2012 and A. oblata Bond-Buckup and Santos, 2012 and the critically endangered A. renana Bond-Buckup and Santos, 2010 and A. brevipalma Bond-Buckup and Santos, 2012 (Santos et al. 2009; 2010; 2012).

Forty-two species are present in Brazilian rivers and 24 are found in rivers in Brazil's southernmost state, Rio Grande do Sul (Bond-Buckup et al., 2008; Bond-Buckup et al., 2010; Santos et al., 2010). This state includes three hydrographic regions, with the Uruguay hydrographic basin being the largest and covering an area of 126,964.24 $\mathrm{km}^{2}$ (Secretaria do Meio Ambiente - RS). Despite its large size, only 11 Aegla species have been described in this region so far (including three species from the bordering southern State of Santa Catarina).

Efforts to catalogue and describe new species are crucial for biodiversity conservation. This is especially true for freshwater organisms, since the knowledge of the total diversity of fresh waters is very incomplete. Our knowledge of the fundamental units of biodiversity are especially lacking among invertebrates and microbes, particularly in the tropical latitudes that support most of the world's diversity (Dudgeon et al., 2006). Moreover, global freshwater biodiversity has declined at higher rates than biodiversity from either marine or terrestrial habitats (Sala et al., 2000; Dudgeon et al., 2006; WWF, 2012). Here we expand our current knowledge of the freshwater biodiversity of Aegla in the Uruguay hydrographic region by describing two new species and presenting new records of previously described species (Tab. 1). Furthermore, we assess these new species for conservation using the IUCN Red List criteria.

Table 1. Distribution of Aeglidae in the main Sub-basins of the Uruguay River: " $x$ " = present. Sub-basins are numbered as in Figure 1: 1 = Upper Uruguay, 2 = Ijuí, 3 = Icamaquã, 5 = Jaguari, 6 = Ibicuí-Mirim, 7 = Quaraí, 8 = Ibirapuitá and 9 = Santa Maria.

Species

Aegla grisella Bond-Buckup and Buckup, 1994

Aegla jarai Bond-Buckup and Buckup, 1994

Aegla longirostri Bond-Buckup and Buckup, 1994

Aegla manuniflata Bond-Buckup and Santos, 2009

Aegla odebrechtii Müller, 1876

Aegla platensis Schmitt, 1942

Aegla singularis Ringuelet, 1948

Aegla spinosa Bond-Buckup and Buckup, 1994

Aegla uruguayana Schmitt, 1942

Aegla leachi Bond-Buckup and Buckup, 2012

Aegla oblata Bond-Buckup and Santos, 2012

Aegla brevipalma Bond-Buckup and Santos, 2012

Aegla georginae n.sp.

\section{Sub-basins}

x

$\mathrm{X}$

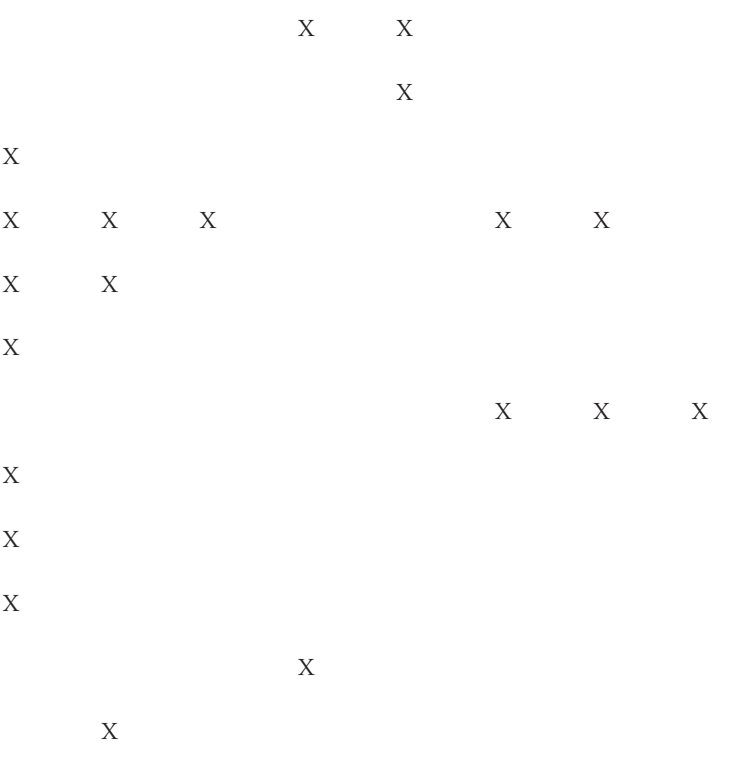




\section{Material and Methods}

Specimens of the two putative new species were collected in Perau Creek, tributary of the Jaguari River (Ibicuí Sub-basin) and in Cambará Creek, a tributary of Potiribu River (Ijuí Sub-basin) (Fig. 1), during several sampling campaigns. All specimens are deposited in the Collections of Crustaceans of the Department of Zoology - Federal University of Rio Grande do Sul (UFRGS), Laboratório de Carcinologia - Universidade Federal de Santa Maria (UFSM) and Museu de Zoologia - Universidade de São Paulo (MZUSP).

The Cambará Creek (28³4'11"S $\left.53^{\circ} 37^{\prime} 15^{\prime} \mathrm{W}\right)$ is a third-order stream, ranging from 5.1 to $8.5 \mathrm{~m}$ in width and from 20 to $50 \mathrm{~cm}$ in depth at the sampled section. It has a rocky bottom and is surrounded by agricultural areas with exposure to agricultural runoff. The Perau Creek (29²9'13”S - 5442'42.6”W), located in Jaguari municipality, has banks with bush vegetation and cattle graze in adjacent areas. The habitat alternates environments with calm and flowing waters, with organic detritus and sandy-rocky substrate. In the section sampled, the creek was 2 to $5 \mathrm{~m}$ wide and ranged from 20 to $50 \mathrm{~cm}$ in depth.

The description of the two new Aegla species is based on the examination of the characters of the type-series. The identification

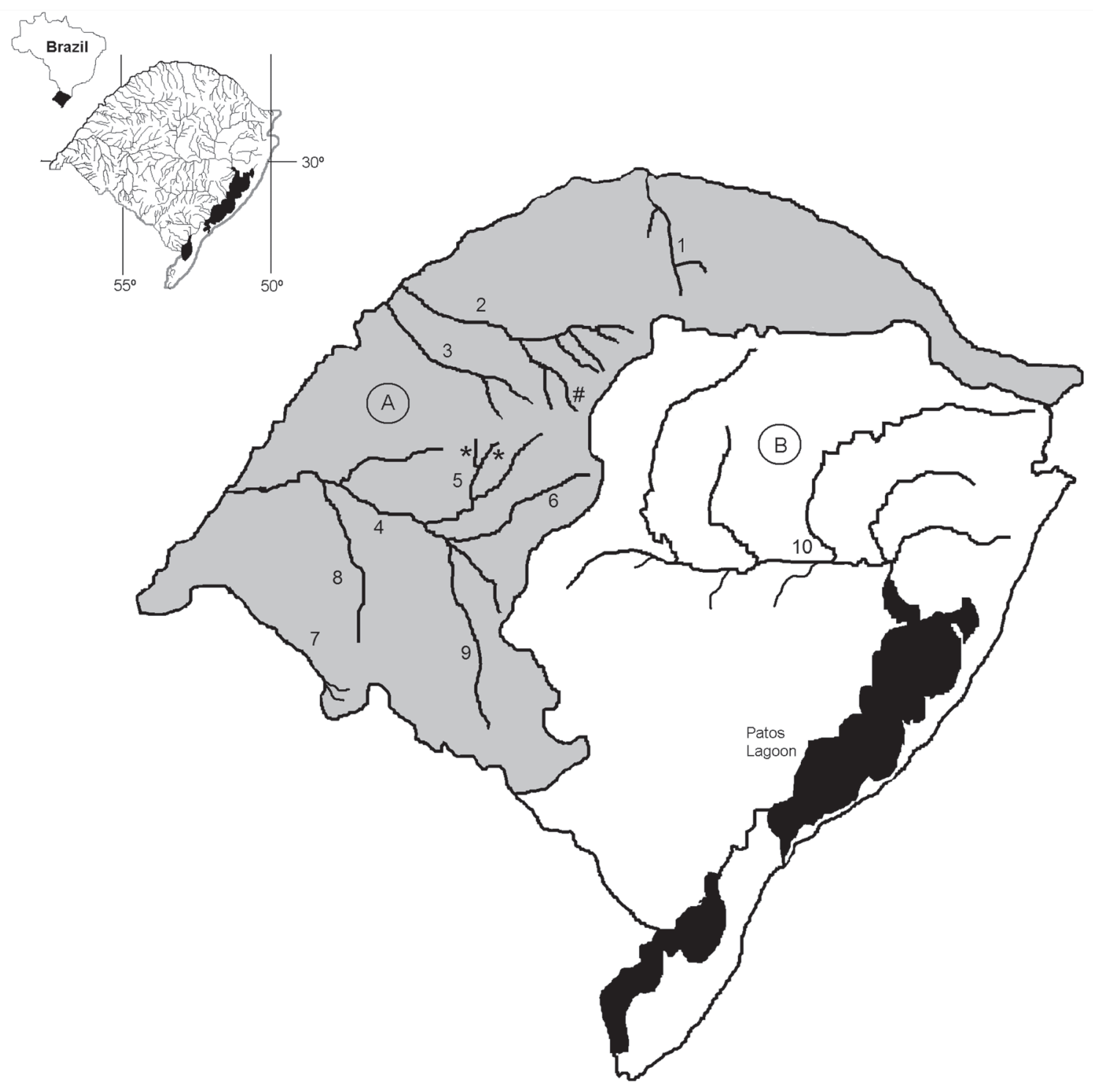

Figure 1. Map of the State of Rio Grande do Sul (Brazil) showing the main hydrographic basins and rivers: (A) Uruguay Basin (gray): 1 Wetland, 2 Ijuí, 3 Icamaquã, 4 Ibicuí, 5 Jaguari, 6 Ibicuí-Mirim, 7 Quaraí, 8 Ibirapuitã, 9 Santa Maria; (B) - Jacuí-Guaíba Basin:

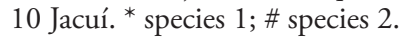


of the other species collected at the same hydrographic basin was confirmed using the key in Bond-Buckup and Buckup (1994). For the measurements of the specimens, the methodology of Bond-Buckup and Buckup (1994) was adopted, with the following abbreviations: Letter " $\mathrm{m}$ " represents males, "f” females, "j" juveniles, CL - cephalothorax length (from the midpoint of the orbital sinus to the midpoint of the posterior margin of the carapace), PCW - precervical width (between the left and right epibranchial margins), FW - frontal width (between the tips of the spines of the antero-lateral angles of the carapace), AL - areola length, AW - areola width, RL rostrum length (between the tip of the rostrum and the midpoint of the orbital margin). MZUSP - Museu de Zoologia da Universidade de São Paulo, São Paulo, Brazil; UFRGS Universidade Federal do Rio Grande do Sul, Porto Alegre, Brazil. UFSM - Universidade Federal de Santa Maria.

Morphometric analysis: For the description of the new species the following body dimensions were recorded for all animals of the type series and also for the non-paratype animals: CL, RL, PCW, FW, AL and AW. The morphometric ratios CL/RL, PCW/FW, and AL/AW were calculated for all animals from each species.

Molecular and phylogenetic analysis: In order to confirm that the two putative new species differ from other Aeglidae previously described not only in morphology but also in molecular characters, we constructed a phylogeny based on the mitochondrial gene COII. Total genomic DNA from four specimens of each of the two new Aegla species was extracted using methods described by Crandall and Fitzpatrick (1996). A segment of the mitochondrial gene COII (568 bp) was PCR-amplified and sequenced, using primers, sequencing conditions and protocols described in Pérez-Losada et al. (2009). Sequences are deposited in GenBank under accession numbers (KC237723-KC237728). The new Aegla sequences were aligned together with those in Pérez-Losada et al. (2009) using ClustalW implemented in Mega5 software (Tamura et al., 2011). The alignment had no ambiguous regions. Maximum likelihood (ML) phylogenies were inferred using RAxML (Stamakis, 2006; Stamakis et al., 2008). One hundred searches were conducted (Stamakis et al., 2008), using the GTR+ $++\mathrm{I}$ model selected by jModeltest2 (Darriba et al., 2012). Branch support was assessed via the rapid bootstrap algorithm (100 replicates) (Stamakis et al., 2008; Pattengale et al., 2010). Aegla papudo Schmitt, 1942 was used as outgroup, since this species was found to be the most primitive Aeglidae, based on morphology (Jara, 1992) and molecular characters (Pérez-Losada et al., 2002; Pérez-Losada et al., 2004).

Conservation assessment: The International Union for Conservation of Nature and Natural Resources (IUCN) set five quantitative criteria that can be applied to assess if a taxon is threatened, and to which threaten category it should be assigned (Critically Endangered, Endangered or Vulnerable). Most of them include sub-criteria to justify the assignment of a taxon within a specific category. To assess the conservation status of these new species, we evaluated their geographic range, which was inferred from sampling efforts in different streams in the surrounding region. The landscape characteristics (land use) at the periphery of their ranges was based on data about forest coverage and evaluated (Fundação SOS Mata Atlântica \& Instituto de Pesquisas Espaciais, 2011: http://mapas.sosma.org.br/).

\section{Results}

Aegla georginae n. sp. Santos \& Jara

(Fig. 2)

Type-material: Holotype male, Brazil, state of Rio Grande do Sul, Perau Creek, tributary of the Jaguari Sub-basin, Jaguari, Rio Grande do Sul, 29²9'13”S - 5442'42.6”W, 07-ii-2009, collected by Legramanti et al., 1 male (MZUSP 27831). 


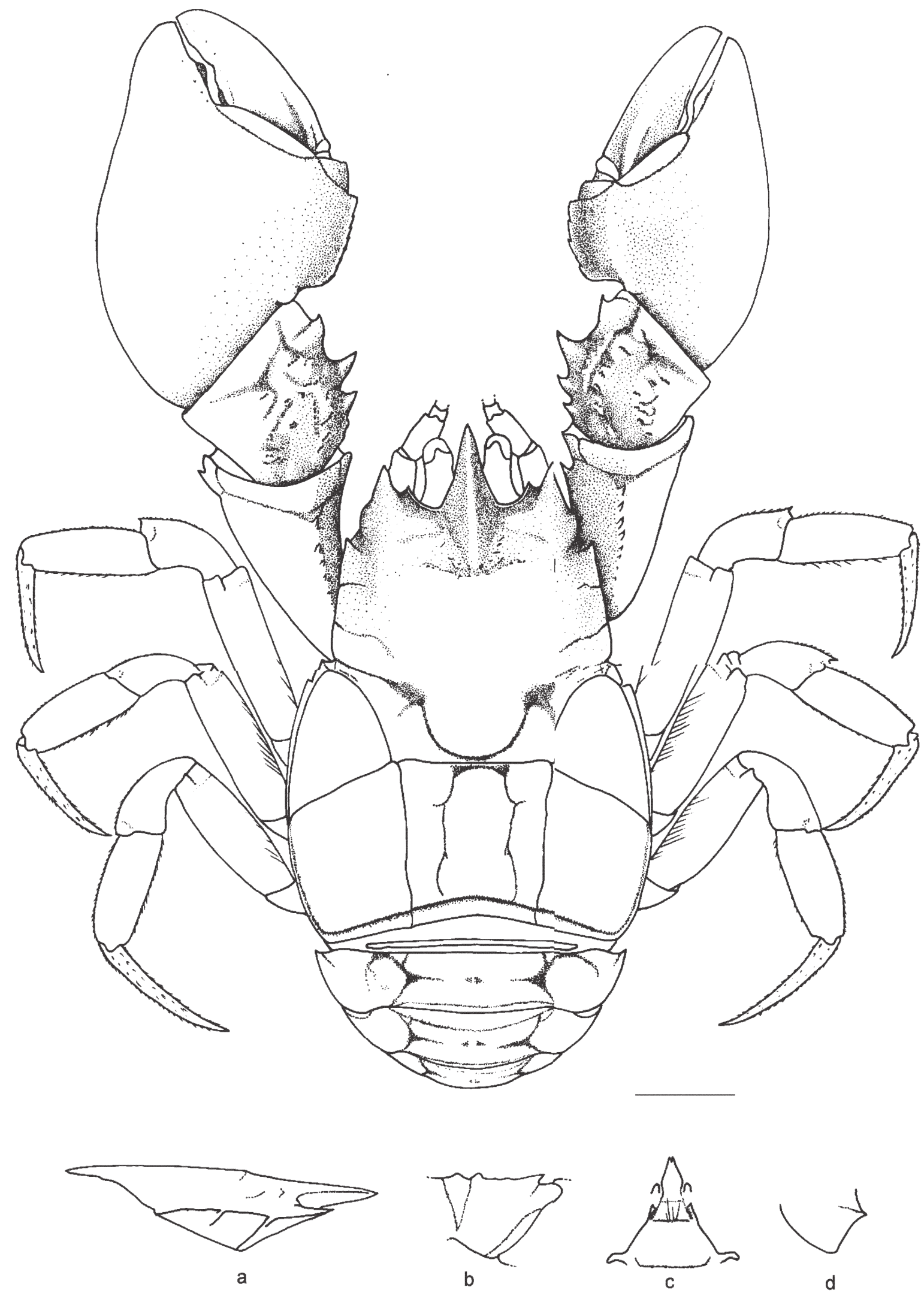

Figure 2. Aegla georginae n. sp., new species: male holotype, dorsal view: (a) precervical portion of carapace, lateral view; (b) ischium of cheliped, ventral view; (c) third and fourth sterna, ventral view; (d) second pleomere epimeron. 
Additional material - Paratypes: $4 \mathrm{~m}$ (UFRGS 5343), same data as holotype; $6 \mathrm{~m}$ and 4f (UFSM 332), Perau Creek, 16.ii. 2009 Legramanti et al.; 2m, 2j (UFSM 328), Tigre Creek, tributary of Jaguari River, Rio Grande do Sul, 5.ii.2009, collected by Santos et al.

Diagnosis: Antero-lateral spine of carapace short, not reaching base of cornea; protogastric lobes present and epigastric lobes very modest; extra-orbital sinus present, U-shaped; rostrum short, carenate; cheliped movable finger without lobe; fingers of both chelipeds with lobular tooth in inner margin; palmar crest of chelipeds subrectangular, both modest and excavated, tending to suboval on the minor cheliped; anterior angle of ventral margin of epimeron 2 with a spine; inner margin of ventral surface of ischium of cheliped with a distal spine, with one to three scales along margin, one proximal tubercle; dorsal margin of dactyle, propod and carpus of the second, third and fourth pereiopods with scaliform tubercles and setae.

Description: Carapace flat, with anterior depression from protogastric lobes; dorsal surface scabrous, covered with punctuations.

Front wide; PCW/FW ratio 1.79 in male holotype.

Rostrum triangular, short [CL/RL $=5.16$ (holotype)]; straight and slightly deflected, larger at base, excavated in median portion. Sub-rostral process developed; in profile, rostrum with equal ventral and dorsal proportions. Rostral carena present from epigastric lobes, with scales irregularly distributed on median portion ending in unique arrow on distal portion with superposed scales. Rostrum lateral margins with scales extending on margin of orbital sinus.

Orbital sinus moderately wide, not deep, C-shaped. Orbital spine present. Extra-orbital sinus U-shaped.

Antero-lateral angle of carapace narrower than first hepatic lobe, anteriorly projected by a scale, not reaching base of cornea. Outer margin of antero-lateral lobe with scales; inner margin with few scales.
First hepatic lobe delimited anteriorly by groove, U-shaped; lateral margin with scales; second hepatic lobe also delimited anteriorly by incision, shallow; third lobe modestly delimited; lateral margins with sub-equal scales.

Epigastric prominences slightly indicated. Protogastric lobes present, not elevated; anterior margin marked by irregular scales.

Transverse dorsal line little sinuous. Areola sub-rectangular, with sub-parallel margins evident along all its extension. Ratio AL/AW of 1.78 (holotype).

Epibranchial area triangular, sub-acute, with one apical spine followed by smaller scaliform tubercles. Lateral margins of anterior and posterior branchial area with sub-equal scaliform tubercles.

Abdome with anterior angle of ventral margin of epimeron two armed with distal spine; ventro-lateral margin almost straight; posterior angle of ventral margin unarmed. Epimera of third to sixth segments projecting; third and fourth lateral projection ornamented with small apical scale.

Telson divided by longitudinal suture.

Anterior extremity of third sternite tapered, projecting between coxae of exopodites of third maxillipeds. Fourth thoracic sternite flat, narrow anteriorly and projected by two tubercles, lateral margins elevated; anterolateral margin projecting.

Right and left propodi of chelipeds with minor sub-rectangular and major sub-oval with slight depression on median portion and presence of many spiniform scales along all extension. Minor propodus with slim aspect and sub-rectangular, also covered by scales and with moderate depression below palmar crest. Both palmar crests sub-rectangular, excavated and with scales on margin. Movable finger lacks lobe. Both dactyli covered with scales. Prehensile margin of fingers with scale-shaped denticles along entire extension and with opposing, dovetailed lobular teeth, with space between fingers. Pre-dactylar lobe ornamented with scales and forming small step with anterior margin of propodus. Articulation 
propodus-carpus with condyle-alveolar shape, ornamented with tubercle on carpus side. Dorsal margin of carpus scabrous, with scales; inner margin with two spines, with distal spine larger than second, followed by up to two tubercles; spines lacking ornamentation, smooth on lateral margins. Carpal crest tipped by sets of scales parallel to inner margin, more featured and robust in proximal region, in both chelipeds; ventral surface with one conical tubercle. Dorsal margin of merus of cheliped with elevations and scaliform tubercles. Lateral surfaces scabrous, with scales and ponctuations. Inner ventral margin of merus with distal spine, with scale on base and two or three tubercles-shaped projections along margin; outer ventral margin with pronounced distal scaliform tubercle. Dorsal margin of ischium with elevation ornamented with scales and tufts of long setae; inner margin of ventral surface with distal spine followed by one to three scales and proximal tubercle.

Dorsal margin of dactylus, propodus, and carpus of second, third, and fourth pereiopods with rows of setae tufts. On dactylus and propods, tufts of setae have velvety aspect. Carpus of second and third pereiopods unarmed.

Measurements: Male holotype with $21.66 \mathrm{~mm}$ CL. Paratypes with mean of 18.56 $\mathrm{mm}$ CL $( \pm 2.54 \mathrm{~mm})$ for males, ranging from 14.4 to $24.0 ; 18.64 \mathrm{~mm} \mathrm{CL}( \pm 1.86 \mathrm{~mm})$ for the females.

Ratio CL/RL of paratypes ranging from 4.87 to 6.57 with mean of $5.50( \pm 0.56)$ for males and $5.53( \pm 0.20)$ for females.

Ratio PCW/FW: paratypes ranging from 1.70 to 1.87 with mean of $1.76( \pm 0.05)$ for males and $1.77( \pm 0.03)$ for females.

Ratio AL/AW: paratypes ranging from 1.64 to 1.85 , mean ratio AL/AW: 1.75 ( \pm $0.07)$ for males and $1.66( \pm 0.13)$ for females.

Etymology: Named in honor of our friend and colleague Dr. Georgina Bond-Buckup, an aeglid specialist who has devoted her career to the excellent study of the biology, taxonomy and systematics of this most interesting group of freshwater crabs.
Biology: Both records of $A$. georginae were at headwaters with preserved riparian forest. At these sites the water was well oxygenated $(>7.0 \mathrm{mg} / \mathrm{L})$ and the conductivity was low $(<50 \mu \mathrm{s} / \mathrm{cm})$, indicating a good water quality. The sampling locations were situated on the hillside of Serra Geral (mountain range), where the river bed was mostly rocky, making the water oxygenation easier. Less than $1 \mathrm{~km}$ apart from the sampling points, the rivers reach the transition zone between Serra Geral and Rio Grande do Sul Peripheric Depression, where the riverbeds tend to be sandy. There are no records of aeglids for these sandy areas.

Distribution: Jaguari River Tributaries, Ibicuí River Sub-basin, Uruguay River Basin, Brazil.

Conservation assessment: ENDANGERED (EN) - (B1-a-biii): B1) Extent of occurrence estimated to be less than $5,000 \mathrm{~km}^{2}$; a) severely fragmented and known to exist at no more than 5 locations; biii) Continuing decline in quality of habitat (IUCN, 2001). The continuing decline can be observed as a constant replacement of native vegetation by pasture or farmlands, mainly along the creeks margins. The municipality of Jaguari originally had $56 \%$ forest coverage, but in 2010 only $9 \%$ of the forest remained. Around 28 hectares of Atlantic Forest were lost just between 2005 and 2008 (Fundação SOS Mata Atlântica \& Instituto de Pesquisas Espaciais, 2011).

Systematics: Morphological and molecular characters confirmed $A$. georginae as a new species. Our ML phylogeny based on the COII mitochondrial gene, although with low clade support, depicted $A$. georginae as sister-species to $A$. renana, and both clustered in the same subclade as $A$. grisella, $A$. longirostri and $A$. spinipalma (Fig. 4). All of these species have palmar crest sub-rectangular $(A$. georginae and $A$. renana) or rectangular ( $A$. longirostri and $A$. spinipalma). Several morphological features differentiate $A$. georginae from $A$. renana: (i) protogastric and epigastric lobes are 
present in $A$. georginae but absent in $A$. renana, (ii) extra-orbital sinus is present in $A$. georginae but absent in $A$. renana, which is probably the most remarkable difference between these two species, and (iii) $A$. georginae has a wide front (ratio $\mathrm{PCW} / \mathrm{FW}=1.79$ male holotype), whereas $A$. renana has a narrow front (PCW/ $\mathrm{FW}=1.95$ male holotype).

\section{Aegla ludwigi n. sp. Santos \& Jara}

(Fig. 3)

Type-material: Holotype male, Brazil, state of Rio Grande do Sul, Cambará Creek, a branch of Potiribu River, tributary of River Ijuí Sub-basin, Cruz Alta, 28³4'11"S 53037'15”W, 27-iii-2009, collected by Copatti et al., 1 male (MZUSP 27832).

Additional material - Paratypes: Brazil: $14 \mathrm{~m}, 3 \mathrm{f}$ and $4 \mathrm{j}$ (UFRGS 5344), same data as holotype.

Diagnosis: Antero-lateral spine of carapace reaching base of cornea; protogastric lobes absent and epigastric lobes modest; extra-orbital sinus present, U-shaped; rostrum medium, carinate along its entire length, recurved distally; movable finger of cheliped without lobe; cheliped fingers with lobular tooth in inner margin; palmar crest of minor cheliped sub-disciform and major cheliped sub-rectangular, both developed and excavated; anterior angle of ventral margin of epimerum 2 unarmed; inner margin of ventral surface of ischium of cheliped with distal spine, one to three scales along margin and proximal tubercle; dorsal margin of dactylus, propodus and carpus of second, third and fourth pereiopods with scaliform tubercles and setae.

Description: Carapace convex, area of gastric region more elevated, dorsal surface scabrous, covered with punctuations.

Front large; PCW/FW ratio of male holotype 1.87 (holotype)

Rostrum triangular, long, ratio CL/RL $=3.67$ (holotype), deflected on distal third. Rostral carena beginning between epigastric prominences, carenate through its entire extension, rostral scales present, with two rows on proximal third and only one on distal portion. Apical portion of rostrum with a tubercle. Rostrum lateral margin with scales. Sub-rostral process, in profile, with ventral portion larger than dorsal.

Orbital sinus moderately broad, deep, U-shaped. Orbital spine present. Orbital margin with scales.

Antero-lateral angle of carapace projecting anteriorly in a scale, which reaches base of cornea. Outer and inner margin of antero-lateral lobe with scales. First hepatic lobe delimited anteriorly by fissure, U-shaped; lateral margins with scales; second and third hepatic lobes not delimited, only indicated by incision; lateral margins with sub-equal scales.

Epigastric prominences moderated, low, indefinite in form. Protogastric lobes absent.

Transverse dorsal line slightly sinuous. Areola quadratic, with ratio $\mathrm{AL} / \mathrm{AW}=1.53$ (mean), sub-parallel distinctive margins along their entire length.

Margins of anterior and posterior branchial region slightly recurved, with scales. Epibranchial area triangular with tubercle.

Anterior angle of ventral margin of epimeron 2 unarmed; ventro-lateral margin slightly concave; posterior angle of ventral margin unarmed. Epimera of third to sixth segments projecting; on third and fourth segments, lateral projection ornamented with apical scale.

Telson divided by longitudinal suture.

Anterior extremity of third sternite truncated, projecting between coxae of exopodites of third maxillipeds. Fourth thoracic sternite flat, lateral margins recurved; antero-lateral margin projecting by lateral tubercle; tuft of transversal setae on anterior part of segment.

Right and left propodi of chelipeds unequal, larger hand sub-rectangular. Proximal outer margin of movable finger without lobe.

Molar process of fingers of cheliped present. Fingers covered by scales and punctuations. Prehensile margins of fingers with scaliform denticles on their entire length, 


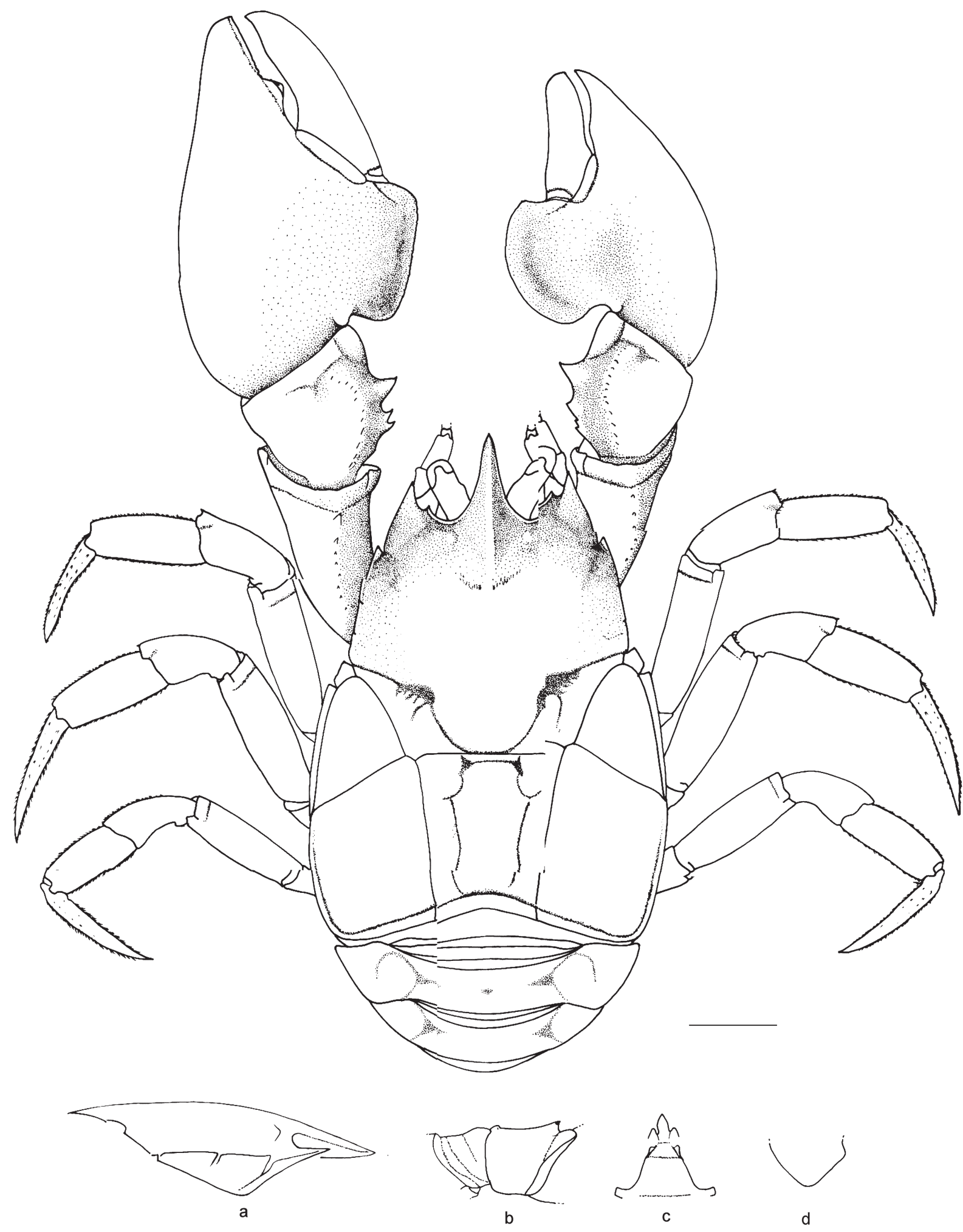

Figure 3. Aegla ludwigi n. sp., new species: male holotype, dorsal view: (a) precervical portion of carapace, lateral view; (b) ischium of cheliped, ventral view; (c) third and fourth sterna, ventral view; (d) second pleomere epimeron. 
and with fitted opposed lobular teeth, with space between fingers.

Palmar crest sub-disciform in minor cheliped and sub-rectangular in major, margins ornamented with scales and excavated in both chelipeds. Median ventral surface of major propodus with carena, ornamented with punctuations and setae, suggesting an elevation.

Dorsal surface of carpus scabrous, with scales; inner margin smooth with two spines, followed by tubercles or scales, without setae; inner antero-lateral angle obtuse, ornamented only with scales; two chelipeds with pronounced carpal crest, elevations ornamented with scales, more featured in proximal portion; ventral surface with a detached tubercle. Dorsal margin of merus of cheliped with distal tubercle and elevations with scales that decrease in size proximally; antero-dorsal margin with sparse scales. Lateral surfaces scabrous, with scales and punctuations. Inner ventral margin of merus with four to five scaliform elevations; in outer ventral margin a distal tubercle shows up. Dorsal margin of ischium with elevation ornamented with scales and tuft of setae; inner margin of ventral surface with a distal spine followed by up to three scales and a proximal tubercle.

Dorsal margin of dactylus, propodus, and carpus of second, third, and fourth pereiopods with rows of setae tufts. On dactylus and propods, tufts of setae with velvety aspect.

Measurements: Male holotype with $25.95 \mathrm{~mm}$ CL. Paratypes with mean of 21.20 $\mathrm{mm}( \pm 5.56) \mathrm{CL}$ for males $(\mathrm{n}=14)$, ranging from 11.16 to 29.78 ; females $(n=2) 16.20$ $\mathrm{mm} \pm 0.19 \mathrm{CL}$.

Ratio CL/RL of paratypes ranging from 2.10 to 3.51 , with mean of $2.65( \pm 0.36)$ for males and $3.01( \pm 0.02)$ for females.

Ratio PCW/FW of paratypes ranging from 1.69 to 1.98 , with mean of $1.85( \pm 0.07)$ for males and $1.87( \pm 0,01)$ for females.

Ratio AL/AW: paratypes ranging from 1.31 to 1.75 , mean ratio AL/AW: $1.56( \pm$ $0.10)$ for males and $1.50( \pm 0.13)$ for females.
Etymology: Named in honor of our friend and colleague Dr. Ludwig Buckup, pioneer in researching freshwater crustaceans in southern Brazil, especially Aeglidae and Parastacidae.

Biology: The species lives in a secondorder stream, tributary to the Potiribu River, where the stream bed alternates between segments with slab covering and segments with sand and rocks of different diameters. Usually the aeglids are found under these rocks. Although there are two other aeglid species living at the same stream section, it seems that they occupy different micro-habitats.

Distribution: Cambará Creek, Potiribu River, tributary of River Ijuí Sub-basin, River Uruguay Basin, Brazil.

Conservation assessment: CRITICALLY ENDANGERED (CR) - (B1-a-biii): B1) Extent of occurrence (EO) estimated to be less than $100 \mathrm{~km}^{2}$; a) severely fragmented and known to exist at only a single location; biii) Continuing decline in quality of habitat (IUCN, 2001). The continuing decline can be observed as a constant replacement of native vegetation by pasture or farmlands, mainly along the creeks margins. According to the most recent report on the relics of Atlantic Forest, this forest accounted originally for 63\% of the overall forest area in Cruz Alta Municipality, where the occurrence area of A. ludwigi is situated. In 2010 only $2 \%$ had been left (Fundação SOS Mata Atlântica \& Instituto de Pesquisas Espaciais, 2011).

Systematics: The molecular phylogeny (Fig. 4) as well as the morphological characters confirms that $A$. ludwigi is a new aeglid species. Based on the COII mitochondrial gene phylogeny, $A$. ludwigi is placed in a subclade with the species $A$. obstipa BondBuckup and Buckup, 1994, A. plana Buckup and Rossi, 1977, A. itacolomiensis BondBuckup and Buckup, 1994 and A. grisella, although with low clade support. Of all these species only $A$. grisella has been recorded in the same hydrographic basin as $A$. ludwigi. These five Aegla species share very few 


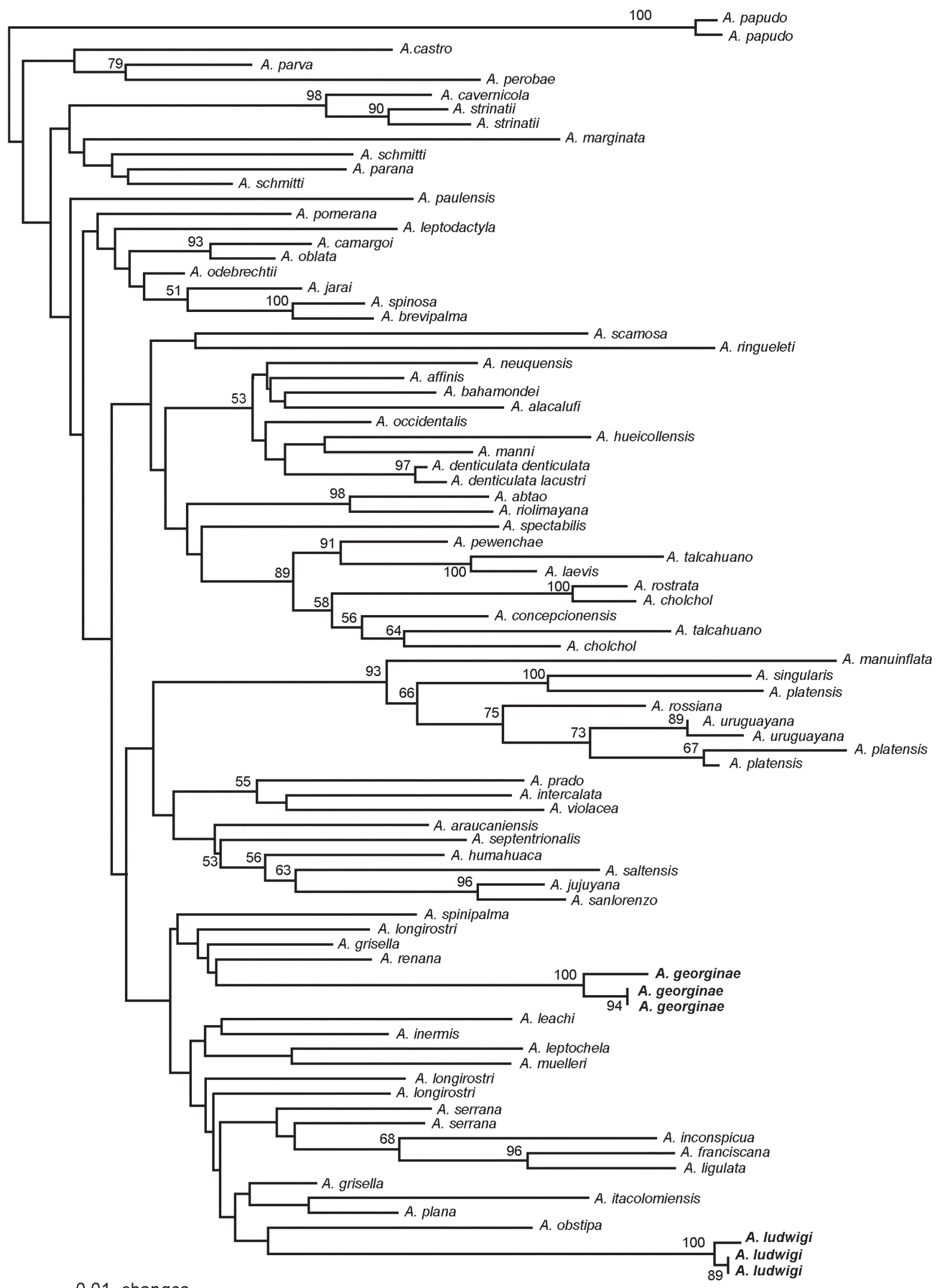

Figure 4. Maximum likelihood tree. Bootstrap proportions (if $>50 \%$ ) are indicated for each clade. Branch lengths are shown proportional to the amount of change along the branches. 
morphological characters such as the absence of protogastric and epigastric lobes and the presence of an outer orbital sinus, modest in A. obstipa. The following characteristics, however, are shared between $A$. ludwigi and A. grisella: convex carapace; rostrum shape, long, entire carenate and deflected; size of the ocular peduncle reaching the base of cornea; large front; movable finger of cheliped lacking lobe; second abdominal epimerum unarmed. However, these two species differ in relation to the palmar crests, while in $A$. grisella these structures are rectangular, in $A$. ludwigi they are sub-disciform in the minor cheliped and sub-rectangular in the major cheliped, both excavated. Our ML tree (Figure 4) depicted A. obstipa as the sister-species to $A$. ludwigi, however, several morphological features distinguish these two taxa: (i) rostrum medium, ligulate and lacking carena in $A$. obstipa versus rostrum long, styliform and carenate in its entire length in $A$. ludwigi; (ii) the extra-orbital sinus is reduced in $A$. obstipa and delimited by only one scale; (iii) the fourth thoracic sternite is flat and lacks antero-lateral projections in A. obstipa, but it has lateral projections in $A$. ludwigi; (iv) A. obstipa presents a narrow front, whereas $A$. ludwigi presents a wide one.

\section{Aeglidae records for the sub-basins of River Uruguay}

Thirteen aeglid species have been described in the River Uruguay Basin (Table 1). Usually these species have restricted distributions, except $A$. platensis Schmitt, 1942 and $A$. uruguayana Schmitt, 1942. A. jarai Bond-Buckup and Buckup, 1994, $A$. odebrechtii Müller, 1876, A. spinosa BondBuckup and Buckup, 1994, A. leachi, A. oblata and $A$. brevipalma are recorded only in the Upper Uruguay River, between the borders of Santa Catarina and Rio Grande do Sul states. Until now, only $A$. georginae has been recorded in the Jaguari River Sub-basin. However, the following four species have been recorded in the Ijuí River Sub-basin: $A$. ludwigi, $A$. singularis Ringuelet, 1948, $A$. platensis and $A$. grisella, and this is the first record of the latter species in the Uruguay Basin. The two latter species occur in sympatry with $A$. ludwigi in the Cambará Creek. Neither morphological features nor molecular phylogenetic analyses suggest the existence of hybrids between $A$. platensis and $A$. grisella. In the latter, samples of $A$. grisella from two different localities were used and they appear as paraphyletic, as already indicated by Pérez-Losada et al. (2004). Further studies are needed to elucidate the taxonomic status of this species.

ACKnowledgements - We thank everyone who collaborated in the collections, particularly Rosemari Parisi Legramanti, Jober Wanderlei Vargas Machado and Carlos Eduardo Copatti. We also thank CNPq for a post-doctorate grant to SS (Proc. 201866/2012-9).

\section{ReFERENCES}

Bond-Buckup, G. and Buckup, L. 1994. A família Aeglidae (Crustacea, Decapoda, Anomura). Arquivos de Zoologia, 32: 159-347.

Bond-Buckup, G.; Jara, C.G.; Pérez-Losada, M.; Buckup, L. and Crandall, K.A. 2008. Global diversity of crabs (Aeglidae: Anomura: Decapoda) in freshwater. Hydrobiologia, 595: 267-273.

Bond-Buckup, G.; Jara, C.G.; Buckup, L.; PérezLosada, M.; Crandall, K.A. and Santos, S. 2010. New species and new records of endemic freshwater crabs from the Atlantic forest in Southern Brazil (Anomura: Aeglidae). Journal of Crustacean Biology, 30: 495-502.

Crandall, K.A. and Fitzpatrick Jr., J.F. 1996. Crayfish molecular systematics: using a combination of procedures to estimate phylogeny. Systematics Biology, 45: 1-26.

Crandall, K.A; Fetzner Jr., W. J.; Jara, C.G. and Buckup, L. 2000. On the phylogenetic position of the South American crayfish genera (Decapoda: Parastacidae). Journal of Crustacean Biology, 20(3): 530-540.

Darriba, D.; Taboada, G.L.; Doallo, R. and Posada, D. 2012. jModelTest 2: more models, new heuristics and parallel computing. Nature Methods, 9: 772.

Dudgeon, D.; Arthington, A.H.; Gessner, M.O.; Kawabata, Z.I.; Knowler, D.J.; Leveque, C.; Naiman, R.J.; Prieur-Richard, A.H.; Soto, D.; Stiassny, M.L.J. and Sullivan, C.A. 2006. Freshwater biodiversity: importance, threats, status and conservation challenges. Biological Reviews, 81(2): 163-182.

Fundação SOS Mata Atlântica e Instituto de Pesquisas Espaciais. 2011. Atlas dos remanescentes florestais da Mata Atlântica, Período 2008-2010: São Paulo, 2011, http://mapas.sosma.org.br/.

IUCN (International Union for Conservation of Nature). 2001. IUCN Red List Categories and Criteria, Version 3.1. IUCN, Gland, Switzerland. 
Jara, C.G. 1992. Un nuevo género de Aeglidae (Crust.: Decap.:Anom.)? Archivos de Biología y Medicina Experimentales, 24: R-194.

McLaughlin, P. A., Lemaitre, R. and Sorhannus, U. 2007. Hermit crab phylogeny: A reappraisal and its "fall-out". Journal of Crustacean Biology, 27(1): 97115.

McLaughlin, P.A.; Lemaitre, R. and Crandall, K.A. 2010. Annotated checklist of anomuran decapod crustaceans of the world (exclusive of the Kiwaoidea and families Chirostylidae and Galatheidae of the Galatheoidea) part III - Aegloidea. The Raffles Bulletin of Zoology, Supplement 23: 131-137.

Pattengale, N.D.; Alipour, M.; Bininda-Emonds, O.R.P.; Moret, B.M.E. and Stamatakis, A. 2010. How many bootstraps replicates are necessary? Journal of Computational Biology, 17(3): 337-354.

Pérez-Losada, M., Jara, C.G.; Bond-Buckup, G.; Porter, M.L. and Crandall. K.A. 2002. Anomuran phylogenetic relationships: on the taxonomic positioning of Aeglidae freshwater crabs. Journal of Crustacean Biology, 22(3): 670-676.

Pérez-Losada, M.; Bond-Buckup, G.; Jara, C.G. and Crandall, K.A. 2004. Molecular systematics and biogreography of the southern South American freshwater "crabs" Aegla (Decapoda, Anomura, Aeglidae) using multiple heuristic tree search approaches. Systematic Biology, 53(5): 767-780.

Pérez-Losada, M.; Bond-Buckup, G.; Jara, C.G. and Crandall, K.A. 2009. Conservation assessment of southern South American freshwater ecoregions on the basis of the distribution and genetic diversity of crabs from the genus Aegla. Conservation Biology, 23: 692-702.

Sala, O.E.; Chapin, F.S.; Armesto, J.J.; Berlow, R.; Bloomfield, J.; Dirzo, R.; Huber-Sanwald, E.; Huenneke, L.F.; Jackson, R.B.; Kinzig, A.; Leemans, R.; Lodge, D.; Mooney, H.A.; Oesterheld, M.; Poff, N.L.; Sykes, M.T.; Walker, B.H.; Walker, M. and Wall, D.H. 2000. Global biodiversity scenarios for the year 2100. Science, 287: 1770-1774.

Santos, S.; Bond-Buckup, G.; Pérez-Losada, M.; Bartholomei-Santos, M.L. and Buckup, L. 2009. Aegla manuinflata, a new species of freshwater anomuran (Decapoda: Anomura: Aeglidae). Zootaxa, 2088: 31-40.

Santos, S.; Bond-Buckup, G.; Pérez-Losada, M.; Jara, C.G.; Crandall, K.A. and Buckup, L. 2010. New records and description of a new species of Aeglidae (Crustacea: Anomura) from river basins in Southern Brazil. Nauplius, 18: 79-86.

Santos, S.; Bond-Buckup, G.; Buckup, L.; Pérez-Losada, M.; Finley, M. and Crandall, K.A. 2012. Three new species of Aegla (Anomura) freshwater crabs from the Upper Uruguay River hydrographic basin in Brazil. Journal of Crustacean Biology, 32(4): 529-540.

Stamatakis, A. 2006. RAxML-VI-HPC: Maximum Likelihood-based phylogenetic analyses with thousands of taxa and mixed models. Bioinformatics, 22: 2688-2690.

Stamatakis, A.; Hoover, P. and Rougemont, J. 2008. A rapid bootstrap algorithm for the RAxML Webservers. Systematic Biology, 75(5): 758-771.

Tamura, K.; Peterson, D.; Peterson, N.; Stecher, G.; Nei, M. and Kumar, S. 2011. MEGA5: Molecular Evolutionary Genetics Analysis using Maximum Likelihood, Evolutionary Distance, and Maximum Parsimony Methods. Molecular Biology and Evolution, 28: 2731-2739.
WWF. 2012. Living Planet Report 2012. WWF International, Gland, Switzerland.

Yeo, D.C.; Ng, J.P.K.L.; Cumberlidge, N.; Magalhães, C.; Daniels, S.R. and Campos, M.R. 2006. A global assessment of freshwater crab diversity (Crustacea: Decapoda: Brachyura). Hydrobiologia, 595: 275286. 